\title{
ВНУТРІШНЯ СЕМАНТИКО-СИНТАКСИЧНА КОРЕЛЯЦІЯ ПОХІДНИХ ЧАСОВИХ ПРИЙМЕННИКІВ У СТРУКТУРІ ТЕМПОРАТИВІВ ЗІ ЗНАЧЕННЯМ ПРИБЛИЗНОГО ТА ПРОМІЖНОГО ЧАСУ
}

\author{
ЛЮДМИЛА ДЕРЕВ'ЯНКО \\ Полтавський національний технічний університет імені Юрія Кондратюка, Полтава — Україна \\ derevyanko.adyl@gmail.com; ORCID: 0000-0001-6271-6571
}

\section{ЛІЛІЯ ГАРАЩЕНКО}

Полтавський національний технічний університет імені Юрія Кондратюка, Полтава - Україна liliya.garashenko@gmail.com; ORCID: 0000-0002-0314-0792

\section{WEWNĘTRZNA SEMANTYCZNO-SYNTAKTYCZNA KORELACJA WTÓRNYCH PRZYIMKÓW CZASOWYCH W STRUKTURZE TEMPORATYWÓW ZE ZNACZENIEM CZASU PRZYBLIŻONEGO I POŚREDNIEGO}

\author{
LUDMYŁA DEREWIANKO \\ Połtawski Narodowy Uniwersytet Techniczny imienia Jurija Kondratiuka, Połtawa — Ukraina \\ LILIA HARASZCZENKO \\ Połtawski Narodowy Uniwersytet Techniczny imienia Jurija Kondratiuka, Połtawa — Ukraina
}

STRESZCZENIE. Do głównych tendencji w zakresie współczesnej składni funkcjonalnej należy przede wszystkim semantyzacja, która opiera się na przeorientowaniu badań lingwistycznych na zasadzie „od treści do formy”. Aktualność danego badania uwarunkowana jest koniecznością wielowymiarowej analizy korelacji przyimków wtórnych — składników czasowych przyimkoworzeczownikowych konstrukcji ze znaczeniem czasu przybliżonego i pośredniego oraz analizy korelacji między pochodnymi przyimkami czasowymi zgodnie ze współczesną nauką. Badanie koncentruje się na formalnej strukturze czasowych przyimkowo-rzeczownikowych temporatywów z uwzględnieniem relacji genetycznychwtórnych przyimków czasu, także na wariantach znaczeniowych przez nie 
realizowanych. Przeprowadzono analizę paradygmatów czteroskładnikowych przyimkowo-rzeczownikowych korelatywów ze znaczeniem czasu przybliżonego i pośredniego we współczesnym języku ukraińskim. Stwierdzono, że wtórne przyimki czasowe powodują pojawienie się cech różnicujących we współzależnych przyimkowo-rzeczownikowych strukturach czasowych, dzięki czemu wchodzą w wewnętrzne związki korelacyjne. Specyficzne warianty semantyczne, odcienie stylistyczne i sfera zastosowania są podstawowymi atrybutami różnicującymi przyimkoworzeczownikowe konstrukcje z wtórnymi przyimkami czasowymi.

Słowa kluczowe: przyimek wtórny, konstrukcje przyimkowo-rzeczownikowe, korelatyw, temporatyw, znaczenie czasu przybliżonego i pośredniego

\title{
INNER SEMANTIC AND SYNTACTIC CORRELATION OF DERIVED PRESPOSITIONS OF TIME IN THE STRUCTURE OF TEMPORATIVES OF APPROXIMATE AND INTERMEDIATE TIME
}

\author{
LYUDMILA DEREVYANKO \\ Poltava National Technical Yuri Kondratyuk University, Poltava — Ukraine \\ LILIA GARASCHENKO \\ Poltava National Technical Yuri Kondratyuk University, Poltava — Ukraine
}

ABSTRACT. One of the key trends in modern functional syntax is semantic one aiming to redirect linguistic research according to the principle „from content to form”. The topicality of the proposed study is grounded on the need for a multidirectional investigation of correlations of secondary prepositions which are constituents of temporal prepositional-nominal structures with semantics of approximate and intermediate time as projected to the sentence as a multi-level syntactic unit. The author also elucidates systematic correlations of temporal prepositions derivatives in accordance with their modern scientific research. The article focuses on the formal structure of prepositionalsubstantive temporatives with the obligatory consideration of genetic connections of secondary temporal prepositions, as well as on the semantic shades realized by them. The present fourcomponent paradigms of preposition-noun correlates with approximate and intermediate time values are analyzed in modern Ukrainian. It is proved that derived prepositions of time determine the appearance of differential attributes in the relative preposition-noun temporal structures, which makes the latter enter inner correlations. Specific semantic shades, stylistic markings and the sphere of application are the basic differential attributes of correlative prepositional-substantive structures with secondary temporal prepositions.

Key words: secondary preposition, preposition-noun structures, correlation, temporative, approximate and intermediate time semantics 
$\mathrm{Y}$

сучасній лінгвістиці важливе місце посідають теорії, пов'язані з процесами активної семантизації синтаксису, що базуються на переорієнтації мовознавчих досліджень за принципом “від змісту до форми”. Нові тенденції зумовлюють відповідні корективи у визначенні особливостей категорійної системи й уможливлюють специфічне потрактування мовних синтаксичних одиниць. До кола перспективних проблем сьогодення вважаємо за доцільне внести питання, пов'язані з функціюванням співвідносних прийменниково-іменникових темпоративів. Іманентні властивості й широкий потенціал складників часових прийменниково-субстантивних корелятивів, а також різноманітні особливості їхньої взаємодії досліджують і аналізують у межах цілісної системи, оскільки прикметною ознакою категорії темпоральності $є$ та, що ії утворюють одиниці різних рівнів, пов'язані між собою загальною ідеєю часу.

Особливе зацікавлення викликають прийменники, що відіграють вагому роль у граматичній сфері сучасної української літературної мови. Сполучаючись із іменниками або їхніми субститутами, прийменники $є$ найпоказовішими індикаторами синтаксичних зв' язків і семантико-синтаксичних відношень. Як мовна одиниця, що безпосередньо бере участь в організації текстових структур, а також має високу частоту вживання й впливає на динаміку лексичного складу, прийменник постійно перебуває в полі зору мовознавців. Його дослідження пов'язані з іменами українських і зарубіжних мовознавців: О. Мельничука, І. Кучеренка, А. Колодяжного, 3. Іваненко, І. Вихованця, К. Городенської, А. Загнітка, Г. Балабан, В. Бондаренка, Є. Куриловича, М. Нікольського, Є. Черкасової, А. Шаранди та ін.

Актуальність цієї розвідки зумовлена передусім потребою відстежити співвідношення вторинних прийменників у структурі часових прийменниково-іменникових конструкцій із семантикою приблизного та проміжного часу в проєкції на речення як синтаксичну одиницю, що реалізується на різних рівнях мовної системи, а також необхідністю системного аналізу корелятивних зв'язків між похідними темпоральними прийменниками.

Мета статті - виявити специфіку реалізування внутрішньої семантико-синтаксичної кореляції прийменниково-субстантивних темпоративів 3 вторинними часовими прийменниками, що експлікують значення приблизного та проміжного часу. Об'єкт вивчення - прості речення з прийменниково-відмінковими темпоральними структурами, що реалізують семантику приблизного та проміжного часу, а предмет - прийменниково-іменникові конструкції з похідними часовими прийменниками. Досягнення поставленої мети передбачає розв'язання таких завдань: 1) схарактеризувати прийменниково-субстантивні темпоративи з вторинними часовими прийменниками, що виражають значення приблизного та проміжного часу; 2) описати всі можливі прийменниково-відмінкові корелятиви - репрезентанти семантики при- 
близного та проміжного часу, що структуровані похідними темпоральними прийменниками; 3) вибудувати й репрезентувати парадигми співвідносних темпоративів аналізованої семантики, з'ясувати специфіку їхньої формально-синтаксичної та значеннєвої ієрархій; 4) виокремити диференційні характеристики структур-корелятів.

Простір, pух і час - триєдиний комплекс форм матеріального буття. Однак якщо перші два складники можуть сприйматися органами чуття, то час $\epsilon$ поняттям абстрактним, інтелектуалізованим. Час у лінгвістиці інтерпретують як відображення реально-темпоральної моделі в мові. Щодо цього О. Тарасова зауважує, що неможливо глибоко розкрити поняття часу, не враховуючи характер перцепції темпоральних відношень людською свідомістю та їхнє оформлення засобами мови. Час у мові можна розглядати в складі тих категорій, за допомогою яких установлюють антиномію між лінгвальною та екстралінгвальною діяльністю людини. На думку цієї дослідниці, час належить до понять, що не лише описані засобами мови, а й експліковані в ній самій, у iii словниковому складі та граматичному ладі [Тарасова 1992: 24]. Оскільки фізичний час є об'єктивною категорією, то властива кожній мові система темпоральних відношень повинна бути більшою чи меншою мірою редукованим відображенням загальної моделі часових відношень [Всеволодова 1975:6].

Темпоральність (від лат. temporalis - часовий) - семантична категорія, на основі якої сформовано функційно-семантичне поле [Теория функциональной грамматики 1990: 5]. Вона об'єктивує сприйняття й осмислення людиною часу окреслених ситуацій та їхніх складників щодо моменту мовлення. Темпоральність справедливо називають векторною категорією, тобто такою, для якої характерне визначення напряму [Теория функциональной грамматики 1990: 7]. Темпоральні відношення відображають властивості реального часу [Бондар 1996: 11] та позначають різний перебіг руху в часі [Загнітко 2007: 124]. Вони є стрижнем мовної системи, позаяк тільки через їхню інтеграцію в мові можна з'ясувати особливості репрезентування останньою топологічних і метричних параметрів реального часу. В основі темпоральних відношень лежить порівняння за часом дії. Ці відношення встановлюють зв'язок мови 3 об'єктивною дійсністю, тобто з реальним часом. Для вираження темпоральних відношень у мові використовують низку засобів - „граматичних (морфологічних і синтаксичних), лексичних, а також комбінованих (лексико-граматичних, граматико-контекстуальних тощо)" [Теория функциональной грамматики 1990: 5] (переклад автор. - Л. Д. і Л. Г.). На особливу увагу заслуговують ті синтаксичні засоби, що мають прийменниково-відмінкові структури. Останні, як стверджує А. Габай, є основними експлікаторами часових семантико-синтаксичних відношень [Габай 2011: 39]. Темпоральні прийменниково-іменникові конструкиії — це синтаксичні одиниці, що слугують для реалізування часових взаємовідношень і взаємодій між предметами та явища- 
ми реального світу. Прийменниково-відмінкові структури - репрезентанти часових відношень - знайшли належне висвітлення у працях українських $\mathrm{i}$ зарубіжних лінгвістів. У просторі української мовознавчої концепції різні аспекти функціювання темпоральних конструкцій висвітлені в граматичних студіях В. Барчука, О. Бондаря, І. Вихованця, Т. Голосової, О. Задорожної, 3. Іваненко, П. Каньоси, Р. Куцової, С. Романюк та інших учених. У русистиці часові сполуки вивчали А. Кока, В. Філіппова, О. Бондарко, М. Всеволодова, Г. Золотова й ін.

У структурі прийменниково-відмінкової форми на семантико-синтаксичному рівні прийменник має синтаксемотвірний потенціал. Темпоральні синтаксеми кваліфікують як різновид вторинних предикатних синтаксем [Вихованець 1992: 140]. Як дериваційна морфема прийменник виконує важливі функції в структуруванні часової синтаксеми й водночас є одним з маркерів темпоральних відношень у реченні. Крім формально-синтаксичної, прийменник виконує ще й семантичну функцію, що полягає в ,конкретизації ролі іменника в денотативній структурі висловлення" [Всеволодова 2003: 34] (переклад автор. - Л. Д. і Л. Г.). У складі прийменниково-іменникових темпоративів використовують часові прийменники, поєднані $з$ іменниками в непрямих відмінках. Прийменникові конструкції, що функціюють у мові як адвербіалії часу, є складною системою співвідношень, утворюваною семантичними відмінностями різних прийменниково-відмінкових форм 3 однаковими умовами вживання. Саме прийменники, як уважає М. Степаненко, послідовно й виразно виконують функцію семантичного маркера [Степаненко 2004: 391]. Як матеріал для конструювання й вираження форм повнозначних слів прийменники водночас $є$ найпоказовішими актуалізаторами синтаксичних відношень і маркерами семантичних відтінків категорії темпоральності. Ураховуючи викладене, доцільно виокремити семантико-синтаксичну кореляцію, звернення до якої уможливить докладну характеристику всіх чинних співвідношень прийменниково-іменникових конструкцій у системі часових семантико-синтаксичних відношень. Таку кореляцію прийменниково-іменникових темпоративів трактуємо як співвідношення двох чи кількох семантично споріднених або опозитивних часових прийменниково-відмінкових структур, що, передаючи однопланове значення часу, відрізняються певними семантичними відтінками. Термін однопланове значення часу застосовують на позначення окремо взятих складників основних протиставлень темпоральної сфери: одночасність / різночасність, часова попередність / часова наступність, означена тривалість / неозначена тривалість тощо.

Внутрішнім називаємо такий тип семантико-синтаксичної кореляції прийменниково-відмінкових конструкцій, який постає на базі часових прийменників, що належать до того самого розряду за походженням. Отже, цей тип кореляції охоплює темпоративи, утворені за участю або тільки первинних, 
або лише вторинних прийменників, напр.: через хвилину - за хвилину - по хвилині; о цій порі - на цฺю пору - в цчю пору — в цій порі - під цุю пору; до початку зими - перед початком зими; за часів Кочубея - у часи Кочубея; під час огляду — y (в) ході огляду - y (в) прочесі огляду; перед виборами напередодні виборів - у (в) переддень виборів - незадовго до виборів - незадовго перед виборами; у кінці відпустки - на кінець відпустки - під кінець відпустки - при кінці відпустки - перед кінцем відпустки й ін.

Окремий розряд між двома чітко розрізнюваними групами, які вказують на часову попередність або часову наступність, становлять структури, що узагальнено відображають часову приблизність. Корелятиви трикомпонентної парадигми рrep близько + Ngen - prep біля + Ngen - prep коло + Ngen містять указівку на приблизний, орієнтовний час дії. Компонентами виокремлених синтаксем $є$ похідний прийменник близько в структурі темпоратива prep близько + Ngen. Така першість утримується завдяки тому, що в значенні прийменника близько семантика часу проступає прозоріше порівняно з прийменниками біля, коло, напр.: Канадецьь приходив тепер пізніше, виходив десь близько півночі [Вільде 2004: 27]; Уже близько третьої дня Скрипник озвався на мобільник Віталія [Кокотюха 2006: 86]. Модель синтаксеми рrep близько + Ngen використовується в різних стилях. Дещо менш застосовуваними є структури 3 прийменником біля: вони властиві мові художньої літератури, а подеколи трапляються в текстах публіцистичного стилю, напр.: Біля восьмої години до мого столика підсідає Карачапов [Винниченко 2006: 52]; Вже було біля п'ятої години, музей замикався [Гуменна 2004: 261]; Paїа Соломонівна приїхала біля першої дня, віддихуючись від вуличної спеки [Жадан 2006: 45]. Як засвідчує мовний аналіз, темпоративи 3 прийменником коло на позначення часової приблизності не властиві мові сучасних письменників. Вони зафіксовані лише спорадично в художній літературі XIX-XX ст., напр.: Довженко вийшов з каюти десь коло третьої години ночі [Мартич 1991: 113]; Він прожив під сонщем коло ста лім [Довженко 2003: 15]. 3-поміж 2020 проаналізованих темпоративів із вторинними часовими прийменниками виявлено лише три з прийменником коло. У прийменниках біля та коло виразніше актуалізується семантичний відтінок просторової близькості. 3. Іваненко зауважує, що прийменники близько, біля, коло поєднуються зазвичай 3 назвами умовних вимірів часу (година, тиждень, місяц̧ь, рік) і вказують на приблизний термін виконання дії [Іваненко 1969: 45].

У текстах творів сучасних письменників, зокрема постмодерністів, трапляються конструкції з прийменником ближче до, що функціює в сполученні 3 родовим відмінком субстантива (prep ближче до + Ngen) та передає, як і вичленувані вище синтаксеми, значення часової приблизності, напр.: Ближсче до вечора у вагончику-маркеті стало людно [Кокотюха 2006: 180]; Ближсче до ночі взагалі не міг знайти собі місия [Дереш 2008: 101]; Ближче до полудня 
знекровлена бідою Іветта Андріївна Вербицька повернулася з консиліуму [...] [Люко Дашвар 2010: 36]. Прийменник ближче до утворений сполученням препозиціоналізованого прислівника близько в простій формі вищого ступеня порівняння 3 первинним прийменником до. У структурі темпоратива рrep ближче до + Ngen він (порівняно з прийменниками близько, біля, коло) виразніше репрезентує семантику приблизного часу. Високу функційну активність синтаксеми prep ближче до + Ngen передусім у текстах художньої літератури, а також у мові публіцистики забезпечує те, що похідний прийменник ближче до регулярно сполучається із субстантивами часової й нечасової семантики. Наприклад, ця синтаксема поєднується з назвами пірроку (зима, весна, літо, осінь), місяців (січень, лютий, березень, квітень, травень, червень, липень, серпень, вересень, жовтень, листопад, грудень), днів тижня (понеділок, вівторок, середа, четвер, n'ятниця, субота, неділя), частин доби (ранок, обід, полудень, вечір, ніч, світанок, північ), державних і релігійних свят (Новий рік, Івана Купала тощо), назви трапез (сніданок, обід, вечеря), періодів і явищ за церковним, сільськогосподарським та академічним календарями (піст, масляна, сівба, оранка, сесія), періодів відпочинку (відпустка, канікули, перерва, вихідні), подій, пов'язаних з періодом розвитку людського суспільства (повстання, революиія, неп, війна, окупація, колективізація, перебудова, вибори), заходів та форм суспільної організації часу (зліт, збори, конференція, з ’̈зд, мітинг, нарада, урок, лекція, спектакль, концерт, репетиція). Прийменник ближче до, зафіксований у Словнику украӥнських прийменників [Словник українських прийменників 2007: 28], за авторськими спостереженнями, активно функціює в мові. Це слугує підставою для доповнення парадигми темпоративів prep близько + Ngen - prep біля + Ngen — prep коло + Ngen на позначення приблизного часу конструкцією prep ближче до + Ngen. В аналізованій парадигмі панівною є синтаксема prep близько + Ngen, менш поширеними є темпоративи рrep біля + Ngen та prep ближче до + Ngen, найнижчий ступінь функційної активності має структура prep коло+ Ngen. Значення проміжного відрізка часу передають темпоративи prep на рубежі + Ngen — prep на зламі + Ngen — prep на стику (стиках) + Ngen — prep на межі + Ngen. Їхніми компонентами є вторинні прийменникові одиниці на рубежі, на зламі, на стику (стиках), на межі, перші три з яких трактують як прийменникові новотвори [Балабан 2007: 9]. Близькі за значенням і синтаксичні структури рrep на рубежі + Ngen - prep на зламі + Ngen. Синтаксемі prep на рубежi + Ngen притаманний семантичний відтінок 'на межі, на кордоні із чимось', а конструкція prep на зламі + Ngen функціює зі значенням 'на перетині із чимось', напр.: Формування украӥнських національних партій на території Російської імперії на рубежн $X \mathbf{X}$-XX cm.: спроба порівняльного політологічного аналізу [Романенко 2002]; Словом, все адекватно, а оче раптом на зламі століть [я] відчув дискомфорт [...] [Костенко 2011: 5]. 
У художньому стилі зафіксовано темпоратив prep на переломі + Ngen, семантично споріднений з попередніми конструкціями, а також оказіонально вживану синтаксему prep на перевалі + Ngen, напр.: Батько помер вчасно, на переломі епох, коли з дерева життя посипались ті, комувін прислужував, перед ким блазнював, зміна епох батькові видалася кінщем світу [Дрозд 1999: 5]; Мов запізнілих подорожніх, Колись, на перевалі літ, Вогнем пречистим $i$ тривожним Покличе нас забутий світ [Нікітін 1989: 47]. Прийменникові еквіваленти на переломі, на перевалі не зафіксовані в Словникові українських прийменників, не виявлено їх і з-поміж прийменникових новотворів у концепції Г. Балабан [Балабан 2007]. Вагомим аргументом для кваліфікування цих одиниць як прийменникових еквівалентів-неологізмів темпоральної семантики $є$ регулярна їхня сполучуваність із субстантивами на позначення часу. Темпоративи prep на переломі + Ngen - prep на перевалі + Ngen органічно доповнюють парадигму корелятивів, що репрезентують семантику проміжного часу — prep на рубежі + Ngen - prep на зламі + Ngen. Усі прийменникові еквіваленти аналізованої парадигми сполучаються із субстантивами, що збігаються за семантикою (епоха, століття, роки).

Синтаксема prep на стику (стиках) + Ngen, як і попередні, передає темпоральну семантику максимальної близькості, перетину часових вимірів, напр.: На стику століть в чемпіонаті Німеччини, який входить у число найсильніших в Свропі, виступав Олександр Лохманчук [Баскетболіст...]. Словник українських прийменників фіксує одиницю на межі як еквівалент, що вживається в значенні прийменника 3 локативною семантикою [Словник українських прийменників 2007: 188], і водночас подає його в синонімному ряду 3 прийменниковим еквівалентом на рубежі, що експлікує тільки темпоральне значення [Словник українських прийменників 2007: 196]. Мовний аналіз засвідчує, що прийменникова одиниця на межі функціює в мові у складі темпоральної конструкції prep на межі + Ngen, напр.: [...] Я [...] народився на межі двох великих століть [Антоненко-Давидович 1991: 5]; Намежі лютого й березня поліські річки скресають, а у весняну повінь виходять з низьких положистих берегів, розливаються у рукави й протоки [Малиновська 1991: 253]. Темпоратив prep на межі + Ngen розширює парадигму корелятивів prep на рубежі + Ngen - prep на зламі + Ngen - prep на перевалі + Ngen prep на переломі + Ngen - prep на стику (стикаx) + Ngen. Усі вони сполучаються з обмеженим колом іменників, репрезентують споріднену семантику й водночас актуалізують специфічні значеннєві відтінки, що увиразнюються завдяки іменниковому компонентові адвербіалізованої прийменниково-субстантивної форми (рубіж, межа, злам, стик).

Отже, похідні, або вторинні, прийменники в складі конструкцій з темпоральним значенням активно й послідовно вступають у корелятивні зв'язки. Семантику приблизного та проміжного часу репрезентують темпоративи 
чотирикомпонентних парадигм корелятивів. Близька або споріднена часова семантика може бути реалізована групою співвідносних форм, що становить передумови для виникнення синонімних прийменниково-іменникових структур. Корелятивність як найістотніша ознака кореляції, що грунтується на взаємозалежності, взаємозумовленості, співвідносності, утворює основу для виникнення синонімічних зв'язків. 3-поміж головних диференційних ознак, спираючись на які можна визнати розглянуті темпоративи з вторинними часовими прийменниками як корелятиви, виділяємо такі: 1) специфічний семантичний відтінок; 2) стилістичне маркування; 3 ) сфера вживання.

\section{Список використаної літератури}

Балабан Г. С., Динамічні процеси в прийменниковій системі сучасної української літературної мови, автореф. ... канд. філол. наук, Київ 2007.

Бондар О. І., Темпоральні відношення в сучасній украӥнській літературній мові: Система засобів вираження, Одеса: Астропринт, 1996.

Вихованець I. Р., Нариси з функиіонального синтаксису, Київ: Наукова думка, 1992.

Всеволодова М. В., Предлог: поле и категория (аспект функиионально-коммуникативной грамматики), [в:] „Лінгвістичні студії”, 2003, вип. 11, ч. І, с. 33-38.

Всеволодова М. В., Способы выражения временных отношений в современном русском языке, Москва: Изд-во Моск. ун-та, 1975.

Загнітко А. П., Прийменники у структурі тексту: первинні і вторинні вияви, [в:] „Лінгвістичні студії, 2007, вип. 15, с. 120-131.

Іваненко 3. І., Прийменникові конструкиї часу в сучасній українській мові, Чернівці: Рута, 1969.

Куцова Р. А., Відтворення темпоральності прийменниковими конструкиіями сучасної української мови, дис. ... канд. філол. наук, Харків 1997.

Словник украӥнських прийменників. Сучасна украӥнська мова: [1705 прийменників], Донецьк: ТОВ ВКФ „БАО”, 2007.

Степаненко М. І., Просторові поширювачі у структурі простого речення, Полтава: АСМІ, 2004.

Тарасова Е. В., Время и темпоральность, Харьков: Основа, 1992.

Теория функииональной грамматики: Темпоральность. Модальность, Ленинград: Наука, 1990.

\section{Spysok vykorystanoi literatury [References]}

Balaban H. S., Dynamichni protsesy v pryimennykovii systemi suchasnoi ukrainskoi literaturnoi movy [Dynamic Processes in the Prepositional System of Contemporary Ukrainian Literary Language: Thesis Abstract in Philology], avtoref. ... kand. filol. nauk, Kyiv 2007. 
Bondar O. I., Temporalni vidnoshennia v suchasnii ukrainskii literaturnii movi: Systema zasobiv vyrazhennia [Temporal Attitudes in Contemporary Ukrainian Literary Language: Expressions Means syStem], Odesa: Astroprynt, 1996.

Vykhovanets I. R., Narysy z funktsionalnoho syntaksysu [Functional Syntax Essays], Kyiv: Naukova dumka, 1992.

Vsevolodova M. V., Predlog: pole i kategoriya (aspekt funktsional'no-kommunikativnoj grammatiki) [Preposition: Field and Category (Functional and Communicative Grammar Aspect)], [v:] „Linhvistychni studii”, 2003, vyp. 11, ch. I, s. 33-38.

Vsevolodova M. V., Sposoby vyrazheniya vremennyx otnoshenij v sovremennom russkom yazyke [Temporal Relations Expressing Ways in Modern Russian Language], Moskva: Izd-vo Mosk. un-ta, 1975.

Zahnitko A. P., Pryimennyky u strukturi tekstu: pervynni $i$ vtorynni vyiavy [Prepositions in the Text Structure: Primary and Secondary Display], [v:] „Linhvistychni studii”, vyp. 15, s. $120-131$.

Ivanenko Z. I., Pryimennykovi konstruktsii chasu v suchasnii ukrainskii movi [Time Preposition Constructions in Modern Ukrainian Language], Chernivtsi: Ruta, 1969.

Kutsova R. A., Vidtvorennia temporalnosti pryimennykovymy konstruktsiiamy suchasnoi ukrainskoi movy [Temporality Reproduction by Prepositional Constructions in Modern Ukrainian Language Thesis Abstract in Philology], dys. ... kand. filol. nauk, Kharkiv 1997.

Slovnyk ukrainskykh pryimennykiv. Suchasna ukrainskamova: [1705 pryimennykiv] [Dictionary of Ukrainian Prepositions. Contemporary Ukrainian Language: [1705 prepositions]], Donetsk: TOV VKF „BAO”, 2007.

Stepanenko M. I., Prostorovi poshyriuvachi u strukturi prostoho rechennia [Spatial Distributors in the Simple Sentence Structure], Poltava: ASMI, 2004.

Tarasova E. V., Vremya i temporal'nost' [Time and Temporality], KHar'kov: Osnova, 1992.

Teoriya funktsional 'noj grammatiki: Temporal 'nost'. Modal 'nost' [Functional grammar theory: Temporality. Modality], Leningrad: Nauka, 1990.

\section{Список використаних джерел}

Антоненко-Давидович Б., Твори: у 2 m. T. 1: Оповідання. Повісті. Літературний репортаж, Київ: Дніпро, 1991.

Баскетболіст Агафонов став першим за 10 років украӥнцем в чемпіонаті Бундесліги, [в:] Електронний ресурс: https://dt.ua/SPORT/basketbolist-agafonov-stav-pershim-za- 10rokiv-ukrayincem-v-chempionati-bundesligi-160214_html (29.12.2018).

Винниченко В., Записки Кирпатого Мефістофеля: роман, повість, оповідання, n'єса, Харків: Фоліо, 2006.

Вільде Ірина, Сестри Річинські: роман, Київ: Україна, 2004.

Гуменна Д., Дар Евдотеї. Іспит пам'яті, Київ: Дніпро, 2004.

Дашвар Люко, Мати все, Харків: Книжковий Клуб „Клуб Сімейного Дозвілля”, 2010.

Дереш Л., Намір!, Харків: Книжковий Клуб „Клуб Сімейного Дозвілля”, 2008.

Довженко О., Вибрані твори, Харків: Веста; Ранок, 2003. 
Дрозд В., Злий Дух. Із житієм; Пришестя: романи, Київ: Укр. письменник, 1999.

Жадан С., Гімн демократичної молоді, Харків: Фоліо, 2006.

Кокотюха А., Темна вода: роман, Київ: Нора-Друк, 2006.

Костенко Л., Записки украӥнського самашедшого, Київ: А-БА-БА-ГА-ЛА-МА-ГА, 2011.

Малиновська М., Гримучі озера. Полісся: дилогія, Київ: Дніпро, 1991.

Мартич Ю., Зустрічі без прощчань: біографічні розповіді, Київ: Дніпро, 1991.

Нікітін Т., ...І стежки праслов 'янська в 'язь: мандрівка по заповідних місиях Полтавщини, Харків: Прапор, 1989.

Романенко Є., Формування українських національних партій на території Російської імперії на рубежі XIX-XX cm.: спроба порівняльного політологічного аналізу, [в:] Електронний ресурс: http://ekmair.ukma.edu.ua/handle/123456789/9033 (26.12.2018).

\section{Spysok vykorystanykh dzherel}

Antonenko-Davydovych B., Tvory: u 2 t. T. 1: Opovidannia. Povisti. Literaturnyi reportazh [Works in 2 Volumes, Vol. 1: Tales. Stories. Literary Report], Kyiv: Dnipro, 1991.

Basketbolist Ahafonov stav pershym za 10 rokiv ukraintsem $v$ chempionati Bundeslihy [Agafonov, a Basketball Player, Became the First Ukrainian in Bundesliga Championship in the Last 10 Years], [v:] Elektronnyi resurs: https://dt.ua/SPORT/basketbolist-agafonovstav-pershim-za-10-rokiv-ukrayincem-v-chempionati-bundesligi-160214_html (29.12.2018).

Vynnychenko V., Zapysky Kyrpatoho Mefistofelia: roman, povist, opovidannia, piesa [SnubNosed Mephistopheles' Notes: Novel, Tale, Story, Play], Kharkiv: Folio, 2006.

Vilde Iryna, Sestry Richynski: roman [Richinsky Sisters: Novel], Kyiv: Ukraina, 2004. Humenna D., Dar Evdotei. Ispyt pamiati [Evdoteia's Gift. Memory Test], Kyiv: Dnipro, 2004. Dashvar Liuko, Maty vse [To Have Everything], Kharkiv: Knyzhkovyi Klub „Klub Simeinoho Dozvillia", 2010.

Deresh L., Namir! [Intention], Kharkiv: Knyzhkovyi Klub „Klub Simeinoho Dozvillia”, 2008.

Dovzhenko O., Vybrani tvory [Selected Works], Kharkiv: Vesta; Ranok, 2003.

Drozd V., Zlyi Dukh. Iz zhytiiem; Pryshestia: romany [Evil Spirit. With Life; Advent: Novels], Kyiv: Ukr. pysmennyk, 1999.

Zhadan S., Himn demokratychnoi molodi [The Hymn for Democratic Youth], Kharkiv: Folio, 2006.

Kokotiukha A., Temna voda: roman [Dark Water: Novel], Kyiv: Nora-Druk, 2006.

Kostenko L., Zapysky ukrainskoho samashedshoho [The Ukrainian Madman's Notes], Kyiv: A-BA-BA-HA-LA-MA-HA, 2011.

Malynovska M., Hrymuchi ozera. Polissia: dylohiia [Roaring Lakes. Polissia: Dilogy], Kyiv: Dnipro, 1991.

Martych Yu., Zustrichi bez proshchan: biohrafichni rozpovidi [Meetings Without Farewells], Kyiv: Dnipro, 1991.

Nikitin T., ...I stezhky praslovianska viaz: mandrivka po zapovidnykh mistsiakh Poltavshchyny [And the Proto-Slavic Binding of the Path: a Journey Through Preserved Lands of Poltava Area], Kharkiv: Prapor, 1989. 
Romanenko Ye., Formuvannia ukrainskykh natsionalnykh partii na terytorii Rosiiskoi imperii na rubezhi XIX-XX st.: sproba porivnialnoho politolohichnoho analizu [The Formation of Ukrainian National Parties on the Territory of the Russian Empire on the Turn of XIX-XX Centuries: an Attempt of Comparative Political Analysis], [v:] Elektronnyi resurs: http://ekmair.ukma.edu.ua/handle/123456789/9033 (26.12.2018). 